Peuples indigènes et environnement

4 | 2013

L'invention de l'indigène écologiste

\title{
Learning from 'tribal ancestors:' how the Nazis used Indian imagery to promote a "holistic" understanding of nature among Germans
}

Franck Usbeck

\section{(2) OpenEdition \\ Journals}

Electronic version

URL: http://journals.openedition.org/elohi/553

DOI: 10.4000/elohi.553

ISSN: 2268-5243

Publisher

Presses universitaires de Bordeaux

\section{Printed version}

Date of publication: 1 July 2013

Number of pages: $45-60$

ISBN: 978-2-86781-927-8

ISSN: 2431-8175

Electronic reference

Franck Usbeck, «Learning from 'tribal ancestors:' how the Nazis used Indian imagery to promote a "holistic" understanding of nature among Germans », ELOHI [Online], 4 | 2013, Online since 01 July 2014, connection on 19 April 2019. URL : http://journals.openedition.org/elohi/553 ; DOI : 10.4000/ elohi.553 


\section{Learning from 'tribal ancestors:' how the Nazis used Indian imagery to promote a "holistic" understanding of nature among Germans}

\section{Introduction}

The German fascination with Native Americans has been a tradition of several centuries, beginning with the first reports about the New World and its peoples. The main features of German Indian imagery have evolved in tandem with Romanticism during the early nineteenth century and have evoked the phenomenon of mass euphoria for Indians in the late 1800s, a euphoria which has lasted for more than a hundred years now. The appearance of the Anishinaabe George Copway before the third World Peace Conference in Frankfurt in 1850 already resulted in a media frenzy (Peyer 141-66). Similarly, when chief Edward Two-Two and his troupe of 20 Lakota-Sioux arrived at the Dresden train station in 1913 to work for the local circus Sarrasani, factories and schools closed for the day, and over one hundred thousand people gathered only to watch the unloading of the baggage and procession to the hotel. Two-Two, who died soon thereafter, asked to be buried in Dresden where his tomb is a special attraction of the local Catholic cemetery until this day (Conrad 466). During World War II, Adolf Hitler publicly praised Karl May's Indian character Winnetou as the ideal company commander and military leader (Speer 523). Even today, references to Indians abound in everyday life. One out of many such items is a TV-commercial in which an old Inuit teaches his grandson how to differentiate the tracks of wolf and bear from those of an Audi Quattro in the snow ("Audi Eskimo"). In spring 2009, Secretary of the Treasury Peer Steinbrück (SPD) labeled the Swiss people as "rogue Indians" and called for a punitive raid by what he termed the "international financial cavalry" to help curb German tax evasion into the Swiss "tax reservation" (Zitzelsberger). All these examples reveal the persistence of Indian imagery in Germany, be it in pop culture or politics. 
They also indicate many of the imagined character traits and the clichés related to Native Americans in Germany.

The Nazis' perception of Native Americans and the representation of Indian imagery in Nazi-controlled media built on these older traditions of "German Indianthusiasm" which interwove Romantic notions, cultural despair, and conservative nationalism during the late nineteenth century. These traditions helped construct national identity by asserting the image of Germans as an original indigenous people who were distinct from other Europeans. They also laid bare the intellectual and cultural conflicts in German society: the unease about an increasingly mechanistic understanding of the industrializing world, and the resulting longing for spirituality, originality, and community. Although current cultural anthropology rejects the term "holistic," I would argue its vagueness fits the similarly vague ideas of Germans' relationship with nature among contemporary nationalists and cultural pessimists, as well as their appropriation of Indian imagery to promote a notion of German indigeneity. Focusing on the interrelations of nationalism, new spiritualism, and racial theory, I argue that the Nazis pragmatically utilized popular tropes of Indian imagery to portray Germans as the Indians of Europe and to present National Socialism as the political and spiritual manifestation of natural law. The Nazis built on transformations in the conservative nationalist movement and pragmatically-in many instances opportunistically-exploited concepts and cultural practices in German culture that promised to work towards their ideological ends and to help rally the people to the Nazi cause. German Indianthusiasm was a phenomenon too popular to be ignored, or even oppressed, by the Nazis. To put it bluntly, "the Nazis would have been stupid not to exploit Indianthusiasm" (Penny).

In this contribution, I will discuss the Nazi regime's propagandistic appropriation of German Indianthusiasm in their discussion of the Germans' relationship to their natural environment. I will start by deliberating cultural debates on the crisis of modernity and the development of dichotomies in which Germans imagined themselves as soul-mates of Indians and as enemies of "the West." Based on these dichotomies, the role of Indian imagery in perceptions of the environment in nationalism and in the reform movements around 1900 will provide the foundations for an understanding of Nazi appropriations of Indian imagery. Finally, I will discuss the Nazis' presentation of Germans as an indigenous people, and the ways in which Nazi propaganda used Indian imagery in

1. Hartmut Lutz coined the term, describing the German euphoria for Indians as «part of an antimodernist, essentially anti-Enlightenment ideologeme, created in a cultural context that constructed ethnicity as blood based, that is interested in escapist folk traditions, and favors genetic-essentialist approaches toward nation-building» (169). 
its environmental and education policies about conservationism and the use of resources.

\section{Cultural despair and two major dichotomous tropes of Indianthusiasm in Germany}

In his classic The Politics of Cultural Despair, Fritz Stern argues that Germany experienced an "undercurrent of anti-liberal belief" during the nineteenth century. He calls it anti-liberal because German conservatives began to lay the blame for social upheaval and class conflict, for alienation, secularization, or urbanization, on the influence of liberal ideas. The resulting rejection of Enlightenment principles as alien is an expression of the traditional rivalry with France and of a sense of inferiority and encirclement (ix-xxv). Rejecting what was perceived as alien led to a rejection of modernity in general among many German conservatives, and to a quest for an alternative sense of "self."

Addressing the same problem, the concept of "counter culture" describes grievances such as a perceived decay of virtues and values, or a sense of disorientation as a result of social upheaval, but it utilizes the other-in this case the exotic Indian-as an idealistic role model to contradict one's own society and its shortcomings in their quest for the self. A number of early examples idealize indigenous peoples in counter-cultural texts, such as Tacitus's descriptions of Germanic tribes, or Montaigne's works on Native Americans (Kohl 29, 40). Romanticism then initiated a cycle of reawakening movements which often occur in the form of alternative subcultures. They usually express their ideas through a demonstrative contempt for current social norms and through the attempt to revive allegedly old traditions. Manfred Schneider coined the term Kulturrecycling to compare early alternative movements, such as the German Lebensreform and the Youth movement around 1900, and their approach to nature and spiritualism, to current youth subcultures (169). Indian imagery and an evolutionist reading of human development allowed these counter-cultural approaches of the nineteenth century to understand Native Americans as models for original, tribal Germans, that is, one needed to observe contemporary Indians in order to understand one's own Germanic ancestors. As scholarship on nationalist projections has demonstrated repeatedly, these Germanic traditions were "neo-traditions that are made up in order to make more palatable breaks with actual traditions or to substantiate politically motivated feelings of peoplehood" (Sollors xii).

While the noble savage was a mirror image in many counter-cultural texts, conservative German nationalists used Indian imagery and the Germanic comparison to declare that Germans had sustained their cultural idiosyncrasies 
against all odds over the last two millenia, but that these idiosyncrasies were now endangered by Western mass society, democracy, and by imperial capitalism. The cultural pessimism Fritz Stern describes explained such historicist constructions by way of idealized dichotomies. Germanic tribes, Native Americans, and contemporary Germans mostly were counted as only slightly different shades of "self", while ancient Romans, the Catholic Church, the French, or the Anglo-Saxon colonial powers were usually assigned the role of the "other."

These dichotomies emerge in the two major features of Indianthusiasm which I detailed in my dissertation. ${ }^{2}$ First, the "Fellow Tribesmen" motif describes a notion of familiarity between Germans and Native Americans, it claims essentialist parallels in social structure, in the relationship with nature, in inheritable national character traits, or even in a mystical spiritual kinship. Seen through Anderson's lense of imagined communities (1983) this construct served German nationalists to distinguish the artificial entity "German people" from all outsiders, to cloak its internal diversity and internal conflicts, and use claims of inherence to provide it with more legitimacy than all previous group identities, be they dynastic powers or religious denominations. Second, the "Common Enemy" motif portrayed France, Great Britain, and the U.S. as threats to the German/Indian self and to the territorial, environmental, and cultural integrity of both Germans and Indians. German-Indian comparison ranged from the conflict between ancient Rome and the Germanic tribes to the American frontier, and eventually to World War I and its aftermath: In all examples, an indigenous tribal society was confronted with the onrush of a materially superior and aggressive settler state. Writer Erhard Wittek (known under the pseudonym Fritz Steuben) framed it in the prologue to one of his Indian novels in the following terms:

Imagine, the old Germanic lands of the time around $1 A D$, with their primitive means of war, their sparse population, their loose alliances of families, clans, and tribes, had been invaded by people from the 1700s or 1800s, equipped with all the weapons of civilization, with all the brutality, recklessness and hypocrisy which civilized peoples have so often shown against the defenseless [...] For two hundred years, the Indians fought against the encroaching white flood [...] and righteousness was always with the permanently betrayed, cheated, and preyedon Redskins. You can compare them to the old Germanic tribes in many another

2. This contribution discusses one aspect of my larger dissertation project. The book manuscript is currently being prepared for publication under the title Fellow Tribesmen: The German Image of Indians, the Emergence of National Identity, and Nazi Ideology in German Periodicals with Berghahn Books, New York. 
aspect [...] Like the Germanic tribes, they lived off hunting and fishing in fortified villages; they had only scant agriculture, they were woodlands peoples, they

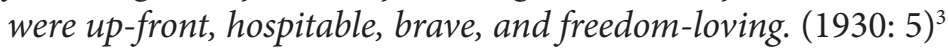

In this quote, both common-enemy and fellow-peoples motifs are united in describing Germans and Indians as similar and having the same enemies by way of historical comparison and by way of imagining a continued twothousand-year existence of Germans as a national entity.

The identification of Germans and Indians by conservative nationalists thus confirmed imagined traditions of Germanic peoplehood and used these idealized dichotomies to set the German people apart from other Europeans. Increasingly, German philosophers, conservatives, proponents of counter-culture and of reform movements underscored this exceptionalist notion by postulating an opposition between the concepts of community and society, as well as between culture and civilization, and thus reflected anti-Enlightenment tendencies. The reception of Ferdinand Toennies's sociological classic Gemeinschaft und Gesellschaft (Community and Society) (1887) reveals that the academic discussion of those concepts served political activists to portray the German people as a natural and organic commonwealth, while Western societies appeared to be artificial and degenerate. Although Toennies does not discuss Native Americans explicitly in his study, his ideas and terminology provided ample opportunity to draw parallels between Germanic and Native American tribes, especially in a society where Indians were becoming a mass phenomenon of popular culture.

Toennies's dichotomy was not a new idea, but his terminology strongly resonated with Indianthusiast popular culture and it provided ammunition for ideological utilization, which can be seen in works such as Werner Sombart's anti-British treatise Merchants and Heroes (1915). German nationalists used these binary concepts to contrast the image of the German forest farmer with that of the paltering Jew, of the chaotic French revolutionary, of the snobby Englishman, or the devious Yankee. One could even read the German national symbol deutscher Michel (sometimes dubbed "Gullible Fritz" in English), as a German Indian: Hobsbawm argues that this idealized self-image of Germans represented a simple(-minded), honest, and trusting backwoodsman who was easily cheated, but who became a fierce enemy when slighted or wronged (276). In many works of fiction and non-fiction, such as Wittek's above quote, the presumably trusting, pure-minded Germans suffered as much as the Indians when confronted

3. If not marked otherwise, all translations of German original quotations are my own. 
with the "brutality, recklessness and hypocrisy" of "civilized peoples," inviting a bond of imagined covictimization between Germans and Indians. If Uncle Sam and John Bull were characterized as clever and sly businessmen in the collective identity of Americans and Britons, an unsuspecting Michel naturally had to appear as a potential victim and, thus, natural enemy to these two figures.

The notion of-apparently typical-German inwardness, the alleged German aversion to politics, permeates the dichotomy of culture and civilization which needs a little more consideration here. Since the Enlightenment era, scholars and philosophers have discussed the binary opposition of "nature" versus "culture" in which indigenous peoples were identified with "nature" and in which their observers assumed the position of "culture," thus denying themselves any relationship with nature and denying the indigenous peoples the ability to be cultured. In German Indianthusiasm and conservative nationalism, however, "nature" and "culture" were increasingly seen as elements of the same category: a people's natural environment determined its cultural development: nature shaped and informed culture. Culture was an organic expression of the "natural state" and of the natural environment of a people; the Germans' forested environment developed a culture related to boreal climate and to forest economy (Herf 138-40). Instead, civilization became the binary opposition to nature/culture: civilization was the embodiment of all alien concepts, it was international and its manifestations, such as liberalism, secularism, and urbanization, were perceived as a threat to both nature and culture.

Toennies's understanding of politics as the negotiation of exclusively confrontative interests confirms the notion of German "inwardness," which Thomas Mann addressed in his Betrachtungen eines Unpolitischen (1918), and which helps explain the dichotomy of culture versus civilization. In the context of the German defeat in World War I, Mann dissociates himself from what he perceives as French concepts. He identifies the eighteenth century with France and calls it fraudulent and effeminate, while declaring himself to be a descendant of the German, somber, and upright nineteenth century. He differentiates between Geist, meaning das deutsche Wesen (the essence of being German), and politics, and concludes:

The difference between Geist and politics includes the difference between culture and civilization, between soul and society, between freedom and franchise, between arts and literature; and Germanness, that is culture, soul, freedom, and arts; and not civilization, society, franchise, and literature. (xxxiii.)

History, adds Mann, would reveal one day that World War I was an assault of internationalism and civilization on Germany and, thus, on German culture 
$(\mathrm{xxxv}) .^{4}$ In this reading, the assault of the alien West results in the rebellious stance and the awakening of the German survival instinct, and it exemplifies the German self-perception as the victims of Western oppression.

\section{The role of the forest environment for the construction of national identity and for reform movements in Germany}

The forest, and the mythologization of nature as a result of the crisis of modernity in general, helped Indianthusiasts throughout the nineteenth and twentieth centuries to conjure up the myth of the special German-Indian relationship. German Romanticists and nationalists often referred to the ancient Germanic tribes as forest dwellers and linked their natural environment to their inherent character. Among others, they quoted Montesquieu's and Tacitus's claims that the Germanic forest culture did not require sophisticated laws to preserve harmony in the community (See 66). More than other symbols, the forest served Romantic notions and helped construe the narrative of continuous German national history from ancient Germania until the present. This narrative lent itself to Indian imagery: "behind [the Indian image] lies concealed that marvelous, early, stage of human development, in which we all lived in the woods, which every young German experiences, and which he should never forget" (Drabsch 184. My emphasis). Thus, both contemporary Native Americans and ancient Germanic tribes were identified as woodlands peoples, and both symbolized the origin of man and the presumed common state of pure and untainted humanity. Their natural environment, the forest, became a symbol of a mother's womb out of which the people emerged, and which was remembered as a dear, safe, and mysterious place, the reservoir of collective memory and of the sense of self. Even where the links between ancient Germanic and contemporary Native American tribes were not made explicit, the parallels in symbolism and imagery facilitated an ominous absent presence of the Indian in German discussions of ancient life in the woods.

Once the forest had gained such symbolic power, it soon came to represent national identity itself, particularly in the image of German oak tree. Character traits, such as honesty, bravery, or inwardness, were declared to be national features of a typical forest-dwelling people. By implication, cities and urbanization were branded as manifestations of chaos, destruction, and alien incursion (Giesen, Junge, and Kritschgau 367-70). This Romantic, primarily anti-western understanding of originality and rootedness resulted in a "parochial contempt

4. Mann later repealed many of these claims and opposed the Nazis who built their ideology on these arguments, but his perception of the war in this quote is representative of conservative nationalist thinking at this time. 
for progress," as Klaus von See has it (62). An element of conservative cultural pessimism, it prevailed throughout the nineteenth and early twentieth centuries (Stern ix). This notion of originality and rootedness was a source of both Indianthusiasm and the corresponding, emerging sense of German exceptionalism in Europe. It allowed to portray both Germans and Indians as Indigenous peoples, that is, as guardians of a sacred home environment who protected it against alien destroyers.

Many of these naturalist and nationalist thoughts informed the concepts of the so-called "Life Reform" movement around 1900. Protagonists of many Life Reform groups sought practical solutions for particularly troubling effects of industrialization and urbanization. ${ }^{5}$ The movement's spiritual and ethical elements often referred to the indigenous Germanic past as well as the indigenous American present, rejecting secularization and an increasingly rational, mechanistic worldview. ${ }^{6}$ This Romantic alternative spiritualism served as a unifier for the diverse strands of the movement, be they youth organizations, progressive reformers, escapist anti-modern Romantics, or pseudo-scientific racial theorists. Proponents of neo-pagan ideas saw materialism and rationalism as a "disenchantment of the world" as Max Weber termed it. Some sought to re-enchant their world by embracing myth, or by assigning religious qualities to abstract concepts, such as the nation (Ulbricht 189-90). This embrace entailed a continuance of reviving old German fairy tales and sagas since the Romantic era, but it also resulted in an increasing interest in the mythology of non-European cultures among some reformers.

As author Franz Kiessling proclaimed in 1902, "our ancestors were, in essence, a genuine indigenous people. Hence, their worldviews and concepts of divinity rested on a simple reverence to their ancestors and to nature" (Qtd. in Gugenberger and Schweidlenka 26). This recently discovered reverence led to spiritual explanations and attempts to rediscover and redefine the natural world, borrowing from Indian imagery as much as from interpretations of old texts about Germanic tribes, and ascribing life and spiritual qualities to virtually everything:

Once again, we are beginning to scent that the many beings which are there beside us are something more than mere masses of facts out of which one would take the most profit and that we must, deep below the threshold of our conscious, somehow stand in a lively relation, in a hidden context, with them. (Hans Kern, qtd. in Rohkrämer 80)

5. For a general introduction into diverse strands, motivations, and major concepts of the movement, cf. the extensive catalog to the 2001 exhibiton in Darmstadt (Buchholz et al.).

6. For introductions to the interconnection to sprirtualism, racism, and esoteric thought, cf. Puschner, Schmitz, and Ulbricht (1999), and Gugenberger and Schweidlenka (1987). 
This quote is exemplary for alternative spiritual concepts among the reform groups. They can be seen as forbears of ideas among today's New Agers, parts of the alternative and hippie cultures, and of the many German hobby-Indian clubs.

\section{Appropriation of Indian imagery and of Indianthusiast tropes for Nazi ideology and environmental policy}

National Socialism was very pragmatic in its application of propaganda; its publications picked up popular themes and employed them for their own purposes. The connection to ancient Germanic ancestors in education, popular culture, and academia was, thus, often made via a discussion of Native Americans. Although it seems to be an oxymoron, the Nazis could promote racism and Indian imagery at the same time: both racial theory and Indian imagery attributed inherent cultural and racial idiosyncrasies to peoples that could not be transferred to others. Nazis, driving Social Darwinism to an extreme, understood their ideology as the application of natural law (Schwenkel 10).

In this sense, it was logical to observe the practices and history of Indigenous peoples (Naturvölker) to draw conclusions about "natural" human behavior (Mühlmann 89). The solidarity, mutual aid, and group cohesion of Indigenous peoples, for instance, could serve as a role model for the group cohesion of the Nazi Volksgemeinschaft (the community of the people); and this opportunity for propaganda overrode notions of white supremacy that were foregrounded on other occasions. This example not only demonstrates the Nazis' emphasis on the community over the individual, but it also shows the bond Nazis assumed between the cultural understanding of the Indigenous peoples and the Germans' own supposed indigeneity. ${ }^{7}$

One major trope of Indian imagery in these representations of GermanIndian similarities was the supposed German and Indian relationship to nature and its mystic qualities. In a 1938 treatise on the value of adventure novels for Nazi education, Erhard Wittek (who had become famous as a writer of Indian novels) stated that a child, playfully hiding in the woods, experienced the same mysterious chirps and rustles that made Indigenous peoples develop a sense for the supernatural (1938: 69). Civilized peoples had apparently retained this sense in their fairy tales and sagas. Thus, a German child could link to its ancestral origins by way of adventure novels and by playing Indian in the woods.

7. The scope of this essay precludes a detailed discussion of the diverse facets and proponents of Nazi representations of Indian imagery. The spectrum ranges from classifying Indians as subhumans to declaring that they were actually "lost Aryan tribes." The third chapter of my forthcoming book Fellow Tribesmen will discuss expedient classifications and utilizations of imagery by way of racial ideology in depth. 
Increased historical and archaeological research into primeval history and ancient Germanic ancestry revealed the tribal societies' close relationship with nature. Researchers pointed out the connection between natural features and supernatural powers. Nazi ideologists eagerly picked up these findings for their propaganda, which was often explicitly neo-pagan. The following explanation incorporates Romantic notions with a religious elevation of nature and with the racist assertion of German superiority:

In the forest, under the majestic giant trees, you are closer to your god than in the dusky dome of your church. Reverently you hearken to the mysterious murmur: the rustling of the leaves, the ripple of the water, the song of the birds [...] This feeling for nature is not a specter, it is the essence and content of our race. It already made its appearance in our first religious myths and has been with us to this day. (Kirsten 142.)

To implement this magical understanding of nature in the people, the Nazi Forestry Department issued separate "Biological School Areas" to German schools, and teachers were advised to spend as much time as possible in these areas with their students. The teaching about local plants and animals was to be combined with teaching sagas and fairy tales that featured these plants and animals, and with instructions about their value for medicine, food, and industry. Teachers were urged to emphasize the link to the Germanic ancestors and their worship of these plants and animals (Steinsiek 148-49). These didactic concepts invited parallels to the image of the Indian elder telling stories by the campfire at night. As Peter-Michael Steinsiek concludes: "German piety worshiped nature as the place and the revelation of a supreme, all-encompassing, transcendent deity. National Socialism had the features of a natural religion" (158).

During the 1930s, the works of Wilhelm Heinrich Riehl were republished. Riehl had witnessed rapid changes in the German landscape due to urbanization, increased exploitation of natural resources, and industrialized agriculture, during the nineteenth century. His works made a link between a healthy environment and a healthy society, and between the national character of Germans and the forested wilderness. Having originated as an indigenous people, he argued, Germans needed uninhibited nature reserves to keep their spiritual and cultural features alive: "We must preserve the forest, and not simply to keep the fire in our furnaces during the winter, but also to let the blood of our people's life continue to run warm and happily, to let Germany continue being German" (15).

A 1936 article on conservation in Nazi Germany declared this presumably unique German relationship with nature to be a primeval racial and spiritual tradition: 
Love for animals, and for nature as such, is one of the most beautiful and noble German traits. The German is far ahead of all other peoples in this respect [...] This is, ultimately, due to the fact that the German has an entirely different relationship with nature than other peoples. The German's blood, the German's character reveals something that relates back to the ancient past, to the limits of historical memory. Ancient Aryan religious experience [...] lives on in German blood. (Wohlbold 122)

This was echoed in literature about Indians: German translations of "Indian" impostor Grey Owl (Archie Belaney, 1888-1938) provided practical knowledge about nature for German children and instilled in them an awareness of the spiritual relationship between humans and nature: "Primitive man, especially the Indian, has no distinct urge to rule ... he understood himself as part of nature, not as its lord" (qtd. in Gugenberger and Schweidlenka 37). Since their claim to indigeneity made Germans apparently understand and love nature, the Nazis saw Germans qualified as natural-born forest rangers. This approach would apply to flora and fauna, but also to "other" indigenous peoples. Walther Schoenichen, one of the chief conservationists during the Nazi era, argued that, since man and animal were relatives, protecting animal included protecting man. He explains:

"Now that we endeavor to save animal species from extinction, it is even more our duty to ensure that the benefactions of an effective protection be bestowed upon primitive man, the most noble of all creatures still living in their original state." (407)

The Germans' romantic relationship with nature and their memories of tribal ancestors were set in relation to the racial doctrine. It stated that races and, by implication, peoples, owned inheritable character traits and idiosyncrasies which could not be transplanted onto other peoples without destroying their cultural integrity (cf. Schmokel 166). This idea was poignantly phrased in Hitler's Second Book, which was published in a commented version only after the war, and which, again, highlights the dichotomy of culture versus civilization: "One cannot convey culture, which is a general expression of a particular people's life, to any other people with completely different mental predispositions. This would, at best, be possible in a so-called international civilization, which, however, relates to culture like Jazz music to a Beethoven symphony" (Institut für Zeitgeschichte 166.). In accordance with similar statements by Nazi leaders, cultural anthropologists and conservationists argued that National Socialism was the political application of biology, and thus, the manifestation of natural law (Schwenkel 10). Future Nazi colonies, they maintained, would be advantageous for indigenous peoples because German colonizers would nurture those 
peoples' inheritable idiosyncrasies and, to give an example, repudiate the forceful transformation of a pastoral tribe into farmers. Thus, the destruction of colonized peoples through forceful assimilation would be avoided (Mühlmann 533-37; Schoenichen 405-23; Schmokel 173-77). In all these considerations, the history of US-Indian relations and the Native American reservation system were used as examples: The Dawes Act of 1887, by which the allotment of tribally held lands was meant to enforce speedy assimilation of Native people into the white mainstream, had led to the erosion of Native cultures, and its economic effects had caused resignation. German anthropologists watched the rollback of US-Indian policy during the "Indian New Deal" after 1934 very carefully, believing its approach to be a role model for future German colonial expansion since it supported tribal communalism: "The study of American mistakes and of their gradual eradication is of great significance for German colonial policy" (Blome 34-35). As US-Indian and environmental policy were studied in German academia, the prominent denunciation of that policy's mistakes in the German media served to criticize Anglo-Saxon colonialism, and to praise the special bond between Germans and Indians.

To conclude, it must be stated that, although Nazi leaders such as Hitler, Himmler, the ideologist Rosenberg, or the chief agrarian Darré appeared to be proponents of a natural spirituality in many statements, none of them had an "emphatic sense" of nature (Steinsiek 141-42). They were simply interested in a healthy environment for healthy food, which would support racial breeding. Race developed through nature, therefore nature needed to be healthy to keep the race healthy. Blood-and-soil ideology did not canonize nature, it canonized race (141-42). The Nazis' nature mysticism was merely used to bring Life Reformers and völkisch neo-pagans into the fold. The apparent call back to the (indigenous) roots in Nazi propaganda served the unification of the people and the spiritual justification of the Nazis' political measures. The promotion of healing plants and of traditional harvesting methods were supplements in the struggle to provide food and resources in a wartime economy. As a 1982 Green Party conference concluded, Nazi ideology can be described as "quantitatively expansive techno-fascism wrapped in the dramatics of origin myths" (Gugenberger and Schweidlenka 29). It made possible the Nazis' spiritualistic bombast on one hand and the development of technological gadgets like the V-2 rocket, or the Tiger tank, on the other. Spirituality was simply bait for power-promoted when feasible, and curbed when it opposed the political goals of Nazi politics. 


\section{Works Cited}

Anderson, Benedict R.O. Imagined Communities. Reflections on the Origin and Spread of Nationalism. London: Verso, 1983.

"Audi Eskimo." Prod. www.boomride.com. YouTube. 2009. Web. 21 Dec. 2011.

Blome, Hermann, ed. "Bericht über die Arbeitszusammenkunft deutscher Völkerkundler in Göttingen am 22. und 23. November 1940.” Göttingen: Institut für Völkerkunde, 1941.

Buchnolz, Kai et al., eds. Die Lebensreform, Entwürfe zur Neugestaltung von Leben und Kunst um 1900. Katalog zur Ausstellung auf der Mathildenhöhe in Darmstadt 2001. 2 vols. Darmstadt: Häusser, 2001.

ConraD, Rudolf. "Mutual Fascination. Indians in Dresden and Leipzig." Indians and Europe. An Interdisciplinary Collection of Essays. Ed. Colin G. Calloway, Gerd Gemünden, and Susanne Zantop. Lincoln: U of Nebraska P, 1999. 455-73.

Drabsch, Gerhardt. Die Indianergeschichte. Berlin: Wiking, 1938.

Giesen, Bernhard, Kay Junge, and Christian Kritschgau. "Vom Patriotismus zum völkischen Denken: Intellektuelle als Konstrukteure der deutschen Identität." Nationales Bewusstsein und kollektive Identität. Ed. Helmut Berding. Frankfurt: Suhrkamp, 1996. 345-93.

Gugenberger, Eduard, and Roman Schweidlenka. Mutter Erde, Magie und Politik. Zwischen Faschismus und neuer Gesellschaft. Vienna: Verlag für Gesellschaftskritik, 1987.

HaIble, Barbara. Indianer im Dienste der NS-Ideologie. Untersuchungen zur Funktion von Jugendbüchern über nordamerikanische Indianer im Nationalsozialismus. Hamburg: Kovac, 1998.

Herf, Jeffrey. Reactionary Modernism. Technology, Culture, and Politics in Weimar and the Third Reich. Cambridge: Cambridge UP, 1984.

Hовsbawm, Eric. "Mass-Producing Traditions: Europe, 1870-1914." The Invention of Tradition. Ed. Eric Hobsbawm and Terence Ranger. Cambridge: Cambridge UP, 1983. 263-309.

Institut für Zeitgeschichte, ed. Hitlers Zweites Buch. Stuttgart: Institut für Zeitgeschichte, 1961.

Kirsten, W. "Deutsche Waldsehnsucht. Baumkultus der Indogermanen." Gartenkunst 49 (1936): 139.

KoHL, Karl-Heinz. Entzauberter Blick: das Bild vom Guten Wilden und die Erfahrung der Zivilisation. Berlin: Medusa, 1981.

Lutz, Hartmut. "German Indianthusiasm. A Socially Constructed German National(ist) Myth." Germans and Indians. Fantasies, Encounters, Projections. 
Ed. Colin G. Calloway, Gerd Gemünden, and Susanne Zantop. Lincoln: U of Nebraska P, 2002. 167-84.

Mann, Thomas. Betrachtungen eines Unpolitischen. Berlin: Fischer, 1918.

MüHLmann, Wilhelm Emil. Rassen- und Völkerkunde. Lebensprobleme der Rassen, Gesellschaften und Völker. Braunschweig: Vieweg, 1936.

Penny, H. Glenn. Personal interview. 15 Oct. 2007.

Peyer, Bernd. "A Nineteenth-Century Ojibwa Conquers Germany." Germans and Indians. Fantasies, Encounters, Projections. Ed. Colin G. Calloway, Gerd Gemünden, and Susanne Zantop. Lincoln: U of Nebraska P, 2002. 141-66.

Puschner, U., W Schmitz, and Justus H. Ulbricht, eds. Handbuch zur Völkischen Bewegung 1871-1918. Munich: Saur, 1999.

RieHL, Wilhelm Heinrich. Von deutschem Land und Volk. Saarlautern: Hausen, 1938.

Rohkrämer, Thomas. "Natur und Leben als Masstäbe für die Reform der Industriegesellschaft." Die Lebensreform. Entwürfe zur Neugestaltung von Leben und Kunst 1900. Ed. Kai Buchholz et al. Darmstadt: Häusser, 2001. 79-96.

SchмокеL, Wolfe W. Dream of Empire. German Colonialism, 1919-1945. Westport, CT: Greenwood, 1964.

SchNeIder, Manfred. "Zarathustra-Sätze, Zarathustra-Gefühle. Nietzsche und die Jugendbewegung." Die Lebensreform. Entwürfe zur Neugestaltung von Leben und Kunst 1900. Ed. Kai Buchholz et al. Darmstadt: Häusser, 2001. 169-74.

Schoenichen, Walther. Naturschutz als völkische und internationale Kulturaufgabe. Jena: Fischer, 1942.

Schwenkel, Hans. "Biologisches Denken und Naturschutz." Naturschutz. Monatsschrift für alle Freunde der deutschen Heimat 17.7 (1936): 9-11.

SeE, Klaus von. Barbar, Germane, Arier: Die Suche nach der Identität der Deutschen. Heidelberg: Winter, 1994.

Sollors, Werner. The Invention of Ethnicity. New York: Oxford UP, 1991.

Sombart, Werner. Händler und Helden. Berlin: Duncker, 1915.

SpeER, Albert. Spandauer Tagebücher. Frankfurt: Propyläen, 1994.

Steinsiek, Peter-Michael. "Anmerkungen zur Biologisierung des politischen und gesellschaftlichen Lebens im 'Dritten Reich' an Beispielen besonders aus dem Land Braunschweig." Braunschweigisches Jahrbuch für Landesgeschichte 87 (2006): 141-59.

Stern, Fritz Richard. The Politics of Cultural Despair. A Study in the Rise of the Germanic Ideology. Berkeley: U of California P, 1974.

Tönnies, Ferdinand. Gemeinschaft und Gesellschaft: Grundbegriffe der reinen Soziologie. Leipzig: Fues, 1887.

Ulbricht, Justus H. "Die Reformation des 20. Jahrhunderts. Religionswissenschaftliche Anmerkungen $\mathrm{zu}$ bildungsbürgerlichen 
Orientierungsversuchen in der 'klassischen' Moderne." Die Lebensreform. Entwürfe zur Neugestaltung von Leben und Kunst 1900. Ed. Kai Buchholz et al. Darmstadt: Häusser, 2001. 187-91.

Wiтteк, Erhard (Fritz Steuben). “Abenteuerbuch." Jugendschriften-Warte Nov. (1938): 69.

- - -.Der fliegende Pfeil. Eine Erzählung aus dem Leben Tecumsehs aus alten Quellen nacherzählt. Stuttgart: Franckh, 1930.

Woнlbold, H. "Naturbeherrschung-Naturverwandlung." Naturschutz. Monatsschrift für alle Freunde der deutschen Heimat 17.6 (1936): 121-24.

ZItZelsberger, Gerd. "Steinbrück: Streit mit Schweiz-Nervöse Indianer im Steuerreservat” Süddeutsche Zeitung Online. 18 Mar. 2009. http://www.sueddeutsche.de/politik/447/462067/text, 25 May 2009.

Frank Usbeck studied American Studies, Modern and Contemporary History, Journalism, and American Indian Studies at the University of Leipzig and the University of Arizona. He currently holds an administrative position at American Studies Leipzig, sponsored by the German Academic Exchange Service (DAAD). Usbeck earned his Dr. phil in 2010 with a study on the interrelation of the German euphoria for Native Americans with the construction of German national identity, and the eventual utilization of Indian imagery for Nazi propaganda in the German print media during 1930s and '40s. His dissertation has won the Rolf Kentner Dissertation Prize of the Heidelberg Center for American Studies in 2011. In addition to Indigenous studies, Usbeck's research interests are (de-) colonization, social protest, and the cultural history of organized violence. Since 2011, he has been working with the Grassi Museum für Völkerkunde Leipzig in cooperative research projects on material culture and ethnomedicine in the Americas. Frank Usbeck is currently working on a larger project concerning the cultural work of American soldier weblogs (milblogs), which he reads through the lens of traditional warrior ceremonies and practices of community-building among Native American peoples.

Summary: In his contribution, Frank Usbeck analyzes the interrelations between German nationalism, new spiritualism, and the German euphoria for Native Americans, in the context of the eventual appropriation of this euphoria for Nazi propaganda. Focusing on these interrelations, he argues that the Nazis pragmatically utilized popular tropes of Indian imagery to portray Germans as the Indians of Europe and to present National Socialism as the political and spiritual manifestation of natural law. Around 1900, nationalist constructions of an idealized Germanic tribal past informed concepts of social reform groups which tackled the negative effects of secularization, urbanization, and industrialization. Mystifying nature, and (re-)discovering a holistic worldview, these reformers borrowed heavily from popular German Indian imagery. The Nazis eventually portrayed both Germans and Indians as indigenous peoples who protected both their cultural integrity and their natural environment against the onrush of Western ideas and the destruction of their homelands by international capitalist greed.

Keywords: national socialism, indian imagery, national identity, spiritualism, naturalism.

Frank Usbeck a étudié la littérature et la civilisation américaines, l'histoire contemporaine, le journalisme et les études amérindiennes à I'Université de Leipzig et I'Université d'Arizona. II occupe actuellement un poste administratif dans le département d'Études Américaines de l'Université de Leipzig, financé par le DAAD (service d'échange universitaire allemand). Usbeck a soutenu en juillet 2010 une thèse sur les liens entre l'enthousiasme allemand pour les Amérindiens et la construction d'une identité nationale allemande ainsi que sur l'utilisation éventuelle de l'imagerie indienne par 
la propagande nazie dans la presse écrite des années 1930 et 1940 . Sa thèse a obtenu le prix Rolf Kentner du Heidelberg Center for American Studies en 2011. Outre son intérêt pour les études indigènes, Usbeck travaille également sur la (dé)colonisation, les mouvements de contestation sociale et l'histoire culturelle de la violence organisée. Depuis 2011, il collabore avec le Grassi Museum für Völkerkunde de Leipzig sur un projet de recherche concernant la culture matérielle et l'ethnomédecine sur le continent américain. Il travaille aussi actuellement sur un vaste projet visant à étudier les weblogs de soldats américains à travers le prisme des cérémonies guerrières traditionnelles et des pratiques communautaires chez les Amérindiens.

Résumé : Frank Usbeck analyse les relations entre le nationalisme allemand, une quête nouvelle de spiritualité et l'enthousiasme des Allemands pour les Amérindiens, sous l'angle d'une appropriation de cet enthousiasme par la propagande nazie. II soutient que les Nazis ont utilisé de manière pragmatique des tropes de l'imagerie indienne afin de représenter les Allemands comme les Indiens de I'Europe et le National-Socialisme comme la manifestation spirituelle et politique de la loi naturelle. Au début du $\mathrm{xx}^{\mathrm{e}}$ siècle, les reconstructions nationalistes d'un passé germanique tribal et idéalisé ont façonné les idéaux des groupes de réforme sociale qui s'attaquaient aux effets négatifs de la sécularisation, de l'industrialisation et de l'urbanisation. Glorifiant la nature et (re)découvrant une vision du monde holistique, ces réformateurs ont largement emprunté à l'imagerie populaire des Indiens tells qu'ils étaient vus par les Allemands. Les Nazis ont fini par présenter les Allemands et les Indiens comme des peuples indigènes, qui protégeaient leur intégrité culturelle ainsi que leur environnement naturel contre les assauts des idées occidentales et la destruction de leurs patries par le capitalisme international.

Mots-clés : National-Socialisme, imagerie indienne, identité nationale, spiritualité, naturalisme. 